\title{
Determinants of Financial Inclusion in West African Economic and Monetary Union (WAEMU) Countries
}

\author{
Ibrahim Chaibou Oumarou, ${ }^{1,2}$ Mayoukou Celestin'2 \\ ${ }^{1}$ Central Bank of West African State, Niamey, Niger \\ ${ }^{2}$ CREAM, University of Rouen-Normandie, Rouen, France \\ Email: ibrahimchaibou.oic@gmail.com, celestin.mayoukou@univ-rouen.fr
}

How to cite this paper: Oumarou, I. C., \& Celestin, M. (2021). Determinants of Financial Inclusion in West African Economic and Monetary Union (WAEMU) Countries. Theoretical Economics Letters, 11, 489-506.

https://doi.org/10.4236/tel.2021.113033

Received: May 2, 2021

Accepted: June 13, 2021

Published: June 16, 2021

Copyright $\odot 2021$ by author(s) and Scientific Research Publishing Inc. This work is licensed under the Creative Commons Attribution International License (CC BY 4.0).

http://creativecommons.org/licenses/by/4.0/

\begin{abstract}
This paper analyzes the determinants of financial inclusion and proposes an instrument of measuring financial inclusion in West African Economic and Monetary Union (WAEMU) countries. WAEMU countries do not have a reliable synthetic index to measure their financial inclusion level. The need for an accurate way to assess financial inclusion in the WAEMU zone is imperative because a set of indicators has been adopted within the Regional Financial Inclusion Strategy by the Central Bank of West African States (CBWAS). Our panel regressions reveal that real GDP, mobile phone penetration, and literacy rate have a positive effect on financial inclusion. Conversely, the weight of the rural population and interbank credit is negatively associated with the level of financial inclusion. Agricultural financing via the credit channel that banks grant to the government is likely to increase financial inclusion. We also find a positive impact of rural-oriented literacy on financial inclusion.
\end{abstract}

\section{Keywords}

Financial Inclusion, Determinants, Synthetic Index, WAEMU, Panel Data Analysis

\section{Introduction}

Financial inclusion has become one of the key concerns of governments and international organizations over the past decade. The objective of financial inclusion policies is to provide adapted formal financial services to serve the needs of excluded people, generally the poor, to improve their well-being (Honohan \& Beck, 2007; Bruhn \& Love, 2014). Indeed, an estimated 400 million adults either do not have access to or do not use formal financial services in sub-Saharan Africa 
(Demirguc-Kunt \& Klapper, 2012a). This category of people is even more important in the West African Economic and Monetary Union (WAEMU), according to data from Global FINDEX 2014.

The Central Bank of West African States (CBWAS) has made financial inclusion one of its priorities by adopting a regional financial inclusion strategy. Despite all the attention of the actors involved, to our knowledge there is not enough work on this topic in this zone. One of the most important aspects that should be addressed is the measurement of the level of financial inclusion. In order to better monitor the evolution of financial inclusion and to better facilitate comparison, it becomes imperative to have a comprehensive and accurate measure of financial inclusion. Currently, WAEMU countries do not have a global vision of their financial inclusion levels. Thus far, evaluations have been based on a number of measurement ${ }^{1}$ indicators adopted as part of the implementation of the regional financial inclusion strategy. This prompts us to ask several questions. After the implementation of an action to increase access to or use of financial services, does this existing set of indicators make it possible to objectively assess the overall level of achievement of that action? Regarding the fact that these indicators are disparate and vary by country, can the WAEMU countries accurately be classified according to their level of financial inclusion, bearing in mind that it would be simplistic to classify them according to one or another of these indicators? Empirically, what factors determine this level of inclusion at the country level? The purpose of our article is to provide adequate answers to all of these concerns.

We can thus analyze determinants of financial inclusion in two ways: through the country characteristics or through the individual characteristics of households or individuals. Analyzing this issue in the case of sub-Saharan Africa, Guerineaun \& Jacolin (2014) show that, from a supply-side view, the following factors contribute to weak banking: excessive banking concentration, the density of banking infrastructure, and the extent of information asymmetries between banks and their potential customers. In terms of demand, it is the low level of GDP per capita in sub-Saharan Africa and the Franc Zone countries and the lower level of education (financial and general) that contribute to the low rate of banking.

Regarding institutional framework, the following elements are at the root of the low level of financial inclusion: poor transport infrastructure, poor business climate, and institutional weakness (macroeconomic and political instability, poor quality of governance, insufficiently favorable business climate, corruption, fragility of the rule of law, etc.). Allen et al. (2016) analyze the foundations of financial inclusion in order to understand individual-level and country-level factors related to holding or using bank accounts in formal financial institutions. They find that improved financial inclusion is linked with a framework to facili-

$\left.{ }^{1} 1\right)$ The demographic penetration rate of financial services, 2) the geographic penetration rate, 3) the strict bank rate, 4) the rate of access to microfinance, 5) the rate of access to e-money, and 6) the real interest rates of deposits and loans. 
tate people's access to financial services, low costs of access to banking services, proximity to financial institutions, a strengthened rule of law, and political stability. Overall, their results show that on the one hand, individual characteristics like age, income, education, and marital status encourage people to use their bank accounts more intensively, and, on the other hand, there exists "an important relationship between financial architecture and financial inclusion" (Allen et al., 2016).

Fungáčová and Weill (2015), studying the case of China in comparison to other BRICS countries, analyze the characteristics of financial inclusion. They consider owning a credit account or saving to be a proxy for financial inclusion. They find the factors that positively influence financial inclusion to be high income, high education level, being male, and being old. These determinants are common to all BRICS countries. However, there are disparities between savings and financial exclusion factors.

Even if financial inclusion is seen to reduce poverty and stimulate economic development, understanding its determinants is a major problem in Africa. Zins and Weill (2016) reveal a low level of financial inclusion in Africa compared to other countries. Gender (being male), income level (being rich), and education level (being educated) promote financial inclusion, with a greater marginal effect on income level and education variables. These results show that, in terms of economic policies related to strengthening financial inclusion, women and young people are the population groups that should be targeted.

In this paper, we will dwell exclusively on country characteristics to analyze financial inclusion determinants. Our purpose is to econometrically analyze country characteristic factors that explain the level of financial inclusion. In this way, we are going to build a multidimensional synthetic index that will evaluate the level of financial inclusion of WAEMU countries and which will be the dependent variable of our econometric model. There are two reasons for this goal: the first is to try to correct the inadequacy of the current method at the WAEMU level in order to show an objective and precise financial inclusion measurement. The second is to be able to formulate policy implications for the model variables that influence (positively or negatively) financial inclusion level.

The rest of this paper is organized as follows: The review of literature is presented in Section 2. Section 3 is dedicated to the methodology used to compute the synthetic index of financial inclusion (SIFI) and the econometric analysis of its determinants. Section 4 will discuss the results. Section 5 provides the conclusion along with some implications in terms of economic policies.

\section{Literature Review}

In the literature, financial inclusion is defined in relation to financial exclusion, its opposite. Several authors have attempted to give a definition of financial exclusion along the lines of Leyshon (1995), who define it as a set of "processes that serve to prevent certain social groups and individuals from gaining access to 
the financial system". In this regard, Servet (2006) says that "a person finds himself in a situation of marginalization or financial exclusion when he can no longer normally live in his own society because he suffers a severe handicap in access to the use of certain means of payment or settlement, to certain forms of loans and financing, to the means of preserving one's savings and distributing income and expenses over time, as well as to the possibility of insuring oneself against risks to one's own existence and property and to transfer funds and income". Carbo et al. (2005) define financial exclusion as the inability of certain persons in society to access to the formal financial institutions services. Similarly, according to Sinclair (2001), "financial exclusion reflects the inability to access necessary financial services in an appropriate form. Exclusion arises from problems of access to financial services, conditions, prices, marketing or self-exclusion in response to negative experiences or perceptions".

For more than a decade, the literature on the theme of financial exclusion has been enriched in France with the various reports of the Walras Center (1999, 2000, 2001, 2002, 2004). According to Gloukoviezoff (2004), financial exclusion refers to "the process by which a person encounters such difficulties of access and/or use in his or her banking practices that he or she can no longer lead a normal social life in his or her own society". In Demirguc-Kunt and Levine (2008), access to finance is defined as an "absence of cost barriers and non-cost barriers". In another study, financial inclusion is defined as a mechanism to ensure "easy access, availability and use of the formal financial system" at an affordable cost to needy populations (Sarma \& Pais, 2011). For our part, we define a country's financial inclusion as the level its population reaches in terms of accessibility, availability, and degree of usage of financial services offered by formal providers (banks, IMFs, EMEs, postal services, etc.).

The work of Demirguc-Kunt and Klapper (2012b) has helped to establish an international database called Global Findex to systematically provide information about the population's usage and access to financial services at the country level. This fills a huge gap in terms of financial inclusion statistics. Beck et al. (2007) have calculated a set of indicators about usage and access to financial services for 99 countries using survey data from financial institutions. However, this is a collection of disparate indicators that does not provide precise information on the multidimensional nature of financial inclusion. Honohan (2008) presents, for 160 countries, an econometric estimation approach of the proportion of people with an account on a country-by-country basis, based on accounts opened in banks and MFIs, the depth of the banking sector, and GDP. For some countries in the sample, the study utilized data from household surveys. These estimations have many limitations, some of which relate to the inconsistency of dates for investigations carried out over different periods, and some of which relate to units of inquiry.

Given the limitations of the work outlined above, Sarma (2008) innovates by constructing for the first time a composite index called "Index of Financial In- 
clusion" (IFI). This index was constructed by mobilizing the HDI construction methodology for a group of 55 countries. However, Sarma stresses from the outset the complexity of setting up such an index. This results in the difficulty of grouping all the information provided by several indicators ${ }^{2}$ into a single index. In constructing an index, there are various approaches: the averaging approach, the Main Component Analysis (MCA) approach, and the distance approach. Sarma's work uses the distance approach, which is based on the calculation of the average distances separating any point from a point that reflects the best situation and from another point associated with the worst situation. It is a system in which two reference points for financial inclusion are identified: one that represents the point of the ideal or maximum situation and another that represents the point of the worst situation or the minimum. Based on these benchmarks, financial inclusion level achieved by a country will be determined.

In addition, other authors (Kidanemariam \& Makina (2015), Chithra \& Selvam, (2013), Sarma \& Pais (2011), Gursharan Singh (2011), Nitin (2012), Kuldeep \& Kondan (2012), etc.) have applied Sarma's method to compute their own composite indices to econometrically analyze determinants of financial inclusion by considering their index as the dependent variable.

Several authors along the lines of Sarma have drawn inspiration from this synthetic index using other approaches. Chakravarty \& Rupayan (2013) use an axiomatic approach to calculate their index from six selected dimensions: geographical, demographic penetration, percentage of deposit accounts, loans, ratio of Deposit/GDP, and ratio of Credit/GDP. This method is quite complex with the insertion of a constant parameter in the formula and several dimensions retained, which could reduce the robustness of this index. In addition, in some countries in the WAEMU, there is no distinction between a deposit account and a credit account.

In Gupte et al. (2012), a geometric average was used to calculate a synthetic index using four dimensions: penetration, use, accessibility, and transaction costs and flexibility of transactions. The structure and nature of the data used make comparison between countries difficult. Measuring flexibility and transaction costs will be controversial or difficult in some countries. Moreover, the method seems too simple and redundant, which could affect the quality of the index measurement.

Sarma (2008) can be criticized for not taking into account the weighting of the different dimensions, but it must be emphasized that Sarma (2015) corrected this limitation by setting up a better index, assigning a weight of 1 to the penetration dimension, 0.5 to the availability dimension, and 0.5 to the usage dimension. Despite the corrections, we consider that the weight attributed to the availability dimension appears to be underestimated, as the information for this dimension is provided in the same way as for the penetration dimension, to which a weight of 1 has been assigned. In addition, usage of financial products

${ }^{2}$ Penetration, Availability, and Usage. 
and services via the internet is very negligible in WAEMU countries. We believe that statistics on banks, IMFs, and ATMs fully reflect the total availability dimension of financial services in this zone.

The index that we construct in this paper is similar to the Sarma index described above. We have adapted it to the WAEMU context. The difference lies in the data ${ }^{3}$ used and their sources. The Sarma index is calculated on the basis of data from the IMF (Financial Access Survey), while we construct our index from data collected directly from financial institutions supervised by the Central Bank. These data are more exhaustive and do not contain any estimates.

\section{Data and Methodology}

\subsection{Data}

All the data that will be used for the SIFI calculation comes exclusively from $C B W A S$ (number of accounts, service points, volume of deposits and loans from banks and IMFs, etc.). Our sample comprises all eight WAEMU countries (Benin, Burkina-Faso, Cote d'Ivoire, Guinea-Bissau, Mali, Niger, Senegal, and Togo) over the period 2004 to 2017 (14 years). For the panel model regression, the source of some explanatory variables (real GDP per capita, agriculture's share of GDP, mobile phone penetration, adult literacy rate, and percentage of rural population) is the "World Development Indicators". Some variables (bank loans granted to the government and interbank borrowing) are taken from the $C B W A S$ database. This database is an important source of information that is posted on its website ${ }^{4}$ regularly and free of charge. It is secondary data, mainly derived from periodic reporting that financial institutions transmit to $C B W A S$ on their activities. These statistics are presented in the form of time series and relate to the real, monetary and financial, public finance, external and social sectors.

\subsection{Computation Method of a Synthetic Index of Financial Inclusion (SIFI)}

Before presenting our calculation method, we first present the indicators that will be retained and highlight the differences with the other indicators previously used, and then methodological choice will be presented of the index.

To assess the progress made in terms of financial inclusion, several indicators are used by financial sector actors. Among the most commonly used indicators are the "Basic Indicators of Financial Inclusion" proposed by AFI. To these indicators we add the amounts of loans and deposits of individuals in the financial system. All of these indicators used individually tend to underestimate financial inclusion by providing partial information. The use of individual indicators tends to compromise the understanding of financial inclusion in a country as we have illustrated in the example below based on the results of Table 1 and Table 2. ${ }^{3}$ We will assign a weight of 1 to the Availability dimension as opposed to the 0.5 given by Sarma. ${ }^{4}$ https://edenpub.bceao.int/. 
Table 1. Set of measurement indicators adopted by $C B W A S^{5}$.

\begin{tabular}{|c|c|c|c|c|c|c|c|}
\hline & $\begin{array}{l}\text { Access to } \\
\text { banks only } \\
\text { (TBS) } \\
\text { (\%) }\end{array}$ & $\begin{array}{l}\text { Access to } \\
\text { IMF only } \\
\text { (TAMF) } \\
(\%)\end{array}$ & $\begin{array}{c}\text { Access to } \\
\text { banks and } \\
\text { IMF (TBE) } \\
(\%)\end{array}$ & $\begin{array}{l}\text { Access to } \\
\text { E-money only } \\
\text { (TAME) } \\
(\%)\end{array}$ & $\begin{array}{c}\text { Access to all } \\
\text { financial services } \\
\text { providers (TUSF) } \\
\text { (\%) }\end{array}$ & $\begin{array}{l}\text { Population Penetration } \\
\text { Rate of Financial } \\
\text { Services (TPSFd) } \\
(\text { for } 10,000)\end{array}$ & $\begin{array}{l}\text { Geographic penetration } \\
\text { rate of financial } \\
\text { services }(\mathrm{TPSFg}) \\
\left(\text { for } 1000 \mathrm{~km}^{2}\right)\end{array}$ \\
\hline BENIN & 25.21 & 36.39 & 61.60 & 22.46 & 84.06 & 7.32 & 37.12 \\
\hline BURKINA & 16.89 & 17.17 & 34.06 & 11.79 & 47.41 & 14.21 & 48.46 \\
\hline C.IVOIRE & 15.95 & 6.25 & 22.20 & 48.91 & 71.43 & 16.66 & 67.10 \\
\hline GUINNEA & 10.59 & 1.11 & 11.70 & 9.66 & 21.36 & 1.00 & 2.44 \\
\hline MALI & 12.30 & 19.78 & 32.08 & 30.88 & 62.96 & 20.79 & 15.42 \\
\hline NIGER & 4.44 & 9.64 & 14.07 & 16.79 & 30.87 & 26.73 & 19.60 \\
\hline SENEGAL & 21.66 & 26.77 & 48.42 & 31.92 & 80.35 & 31.18 & 129.67 \\
\hline TOGO & 20.39 & 44.78 & 65.17 & 3.98 & 69.15 & 3.93 & 27.72 \\
\hline
\end{tabular}

Source: Author's calculations from CBWAS data.

Table 2. Country ranking according to $C B W A S$ measurement indicators.

\begin{tabular}{|c|c|c|c|c|c|c|c|}
\hline Ranking & $\begin{array}{l}\text { Access to } \\
\text { banks only } \\
\text { (TBS) } \\
\text { (\%) }\end{array}$ & $\begin{array}{l}\text { Access to } \\
\text { IMF only } \\
\text { (TAMF) } \\
(\%)\end{array}$ & $\begin{array}{c}\text { Access to } \\
\text { banks and } \\
\text { IMF (TBE) } \\
(\%)\end{array}$ & $\begin{array}{l}\text { Access to } \\
\text { E-money only } \\
\text { (TAME) } \\
(\%)\end{array}$ & $\begin{array}{c}\text { Access to all } \\
\text { financial services } \\
\text { providers (TUSF) } \\
\text { (\%) }\end{array}$ & $\begin{array}{l}\text { Population Penetration } \\
\text { Rate of Financial } \\
\text { Services (TPSFd) } \\
\text { (for 10,000) }\end{array}$ & $\begin{array}{l}\text { Geographic penetration } \\
\text { rate of financial } \\
\text { services }(\mathrm{TPSFg}) \\
\left(\text { for } 1000 \mathrm{~km}^{2}\right)\end{array}$ \\
\hline $1^{\mathrm{er}}$ & BENIN & TOGO & TOGO & C.IVOIRE & BENIN & SENEGAL & SENEGAL \\
\hline $2^{\mathrm{e}}$ & SENEGAL & BENIN & BENIN & SENEGAL & SENEGAL & NIGER & C.IVOIRE \\
\hline $3^{e}$ & TOGO & SENEGAL & SENEGAL & MALI & C.IVOIRE & MALI & BURKINA \\
\hline $4^{\mathrm{e}}$ & BURKINA & MALI & BURKINA & BENIN & TOGO & C.IVOIRE & BENIN \\
\hline $5^{\mathrm{e}}$ & C.IVOIRE & BURKINA & MALI & NIGER & MALI & BURKINA & TOGO \\
\hline $6^{\mathrm{e}}$ & MALI & NIGER & C.IVOIRE & BURKINA & BURKINA & BENIN & NIGER \\
\hline $7^{\mathrm{e}}$ & GUINEA B & C.IVOIRE & NIGER & GUINEA B & NIGER & TOGO & MALI \\
\hline $8^{e}$ & NIGER & GUINEA B & GUINEA B & TOGO & GUINEA B & GUINEA B & GUINEA B \\
\hline
\end{tabular}

Source: Author's calculations from CBWASdata.

In the table below, we rank the different countries by each of the indicators.

Table 1 and Table 2 present the main indicators adopted and used by the $C B W A S$ to compute the level of financial inclusion in WAEMU countries.

Togo, which is ranked first in TAMF and TBE, is in the last position in terms of TAME and 7th (out of 8 ) in TPSFd. Niger, which occupies the penultimate ${ }^{5}$ According to CBWAS, TPSFd represents the number of adults (15 years and over) sharing a point of service. The following are categories of providers of financial service points: Banks, IMF, E-money, Postal services offices, and Treasury. TPSFg is determined by the size of the country and represents the number of service points per 1000 square kilometers.TBS is defined as the percentage of adults holding an account in banks, Postal services offices, and Treasury. TAMF is defined as the percentage of adults holding an account in the IMF. TBE is defined as the percentage of adults holding an account in all providers (banks, SFD, postal services, and Treasury). TAME represents the percentage of adults holding electronic money accounts with Electronic Money Institutions, e-money issuing banks (in partnership with mobile phone operators), and other financial institutions such as the IMF. TUSF is the indicator for measuring the percentage of adults holding an account across all types of financial services providers (banks, IMF, Postal services office, Treasury, and E-money). 
place (7th) for TBE, is in the 2nd position for TPSFd. Senegal exceeds Benin in terms of TPSFd, TPSFg, and TAME, but is behind Benin in TBS, TAMF, and TBE. In other words, reading the table shows that the ranking improves from TBS to TAMF for Togo, Mali, and Niger, which means that these countries have a microfinance sector which is more inclusive than their bank sector. The opposite situation is observed for Benin, Senegal, Burkina Faso, Côte d'Ivoire, and Guinea-Bissau. The use of electronic money is more pronounced in Côte d'Ivoire (1st place) compared to its other indicators. Togo is in the opposite situation and occupies the last place in terms of the use of electronic money, even though it is also in the first place in terms of access to microfinance and expanded banking. Finally, reading the ranking of countries according to the seven individual indicators does not give an objective reading on the global financial inclusion in the Union. It is then difficult to make an orderly ranking of the eight WAEMU countries to see if country has a more inclusive financial system than another. Also, none of these indicators taken individually is sufficient to capture the level of financial inclusion, given its multidimensional nature.

As noted above, our approach is based on Sarma (2015), who calculates a synthetic index of financial inclusion for more than 136 countries over the period 2004 to 2014.

The SIFI will take into account the indicators on both the access dimension and the use of financial services. As the quality dimension is not addressed due to the multiplicity of evaluation criteria and differences in perception between providers and users, it is difficult to find convergent quality criteria (Sangaré, $2013)^{6}$. The indicators that will be included in the SIFI calculation are as follow.

Dimension 1: Access to financial services (penetration rate): According to Alliance for Financial Inclusion (AFI) (2010), this aspect firstly concerns the ability to use the available financial services and products offered by formal financial institutions. An inclusive financial system should have greater penetration among the population of a given space. The size of the banked population, i.e. the proportion of people with an account in a formal financial institution, is a measure of the penetration of the financial system. Thus, if all persons in an economy have a bank account, the value of this measure would be 1 . However, data on the number of people with a bank account is not readily available, and in the absence of these data, we use the number of deposit accounts in the financial institutions per 1000 adults as proxy for the indicator of this dimension. This is justified by the fact that the proportion of the banked population and the number of adult population deposit accounts with institutions per 1000 are positively correlated. For this value, i.e. the number of deposit accounts, we consider the following types of institutions: commercial banks, postal services, microfinance institutions (MFIs) and mobile banking users.

Dimension 2: Availability of financial products and services: Another charac${ }^{6} \mathrm{Ph} . \mathrm{D}$. thesis, "Microfinance: What links between institutional financing models and the quality of services offered to clients?", University of Toulouse 1 Capitole (France), 342 p. 
teristic or dimension of an inclusive financial system is the easy availability of financial services. It is measured by the number of points of services (for banks and MFIs), ATMs, mobile money kiosks or agency of telecom companies, etc. Thus, the indicator of the availability of services can be represented by the number of agencies providing financial services (per 1000), by the number of ATMs for 1000 and possibly the number of mobile money kiosks of telecom companies for 1000. Today, the importance of ATMs in providing better access banking is undeniable in many countries. They play an important role in savings given their flexibility and efficiency, including among other things the provision to customers of their bank account balances, deposits and withdrawals of money etc. This dimension represents all the mechanisms put in place by the formal financial system to provide financial services to populations. Even if the form, the name or the functioning of these mechanisms vary between countries, this dimension materializes in a global way the banks and their different agencies, the microfinance institutions and the electronic money providers in the broad sense. For the case of our study, we use data on the number of branches (banks and MFIs), the number of mobile money providers, and the number of ATMs per 100,000 adults to measure this dimension. Two separate indices are calculated: one for the branches (including bank branches and mobile money agencies), and the second for ATMs. Then, a weighted average of these two indices is calculated, using a weight of $2 / 3$ for the index of branches and banking services and the weight $1 / 3$ is considered for the ATM index (Sarma, 2015).

Dimension 3: Usage of financial products and services: Not limited to the basic adoption of financial services, this aspect places more emphasis on the permanence and intensity of use of the financial services or products (AFI, 2010). Observed by Kempson et al. (2004), this dimension is motivated by the notion of "underbanked" or "slightly banked" populations. The use of financial services can be in several forms, namely in particular with regard to the detail on the regularity, the duration of use and the frequency or even the combination of the services used by the same individual. So this dimension should include data on credits, deposits, payments, remittances, transfers, etc. (Sarma, 2015). Thus, the usage dimension should include measures on all these different forms even if, moreover, the availability of all of these data has been a problem to date. For the present study, we will consider the following indicators for this dimension: credit, deposit, and mobile money transactions as a percentage of GDP.

Like the HDI and according to the work of Sarma (2008), SIFI is calculated on the basis of the three dimensions selected. We adopt a multidimensional approach and start by calculating the index of the different dimensions. The index $d_{i}$ of the $i$ th dimension is given by:

$$
d_{i}=\omega_{i} * \frac{A_{i}-m_{i}}{M_{i}-m_{i}}
$$

where: 
$A_{i}$ : Current value of dimension $i$.

$m_{i}$ : Minimum value of dimension $i$.

$M_{i}$ : Maximum value of dimension $i$.

$\omega_{i}$ : Weight assigned to dimension $i$.

And $0 \leq d_{i} \leq 1$. The higher the $d_{i}$ is, the higher the country's achievements from the point of view of dimension $i$ are. Considering $n$ dimensions, "a country $i$ will be represented by a point $D_{i}=\left(d_{1}, d_{2}, d_{3}, \cdots, d_{n}\right)$ on the Cartesian space of $n$ dimension. In the space of $n$ dimension, point $O(0,0,0, \cdots, 0)$ represents the point indicating the bad situation and point $I(1,1,1, \cdots, 1)$ represents the best situation" (Sarma, 2015).

The Synthetic Index of Financial Inclusion of a country $i$ is measured by the inverse of the normalized euclidean distance of the $D_{i}$ point from the ideal point $I(1,1, \cdots, 1)$ normalized with respect to the formula:

$$
\mathrm{SIFI}_{i}=1-\frac{\sqrt{\left(1-d_{1}\right)^{2}+\left(1-d_{2}\right)^{2}+\cdots+\left(1-d_{n}\right)^{2}}}{\sqrt{n}}
$$

The numerator of the fraction is the Euclidean distance between the point $D_{i}$ and the ideal point $I$. The normalized inverse distance is found by normalizing by $n$ and subtracting by $1, n$ being the number of dimensions retained. The purpose of normalization is to allow reading the index over the 0 to 1 interval. Inverse distance is considered for ease of comprehension-a high SIFI value corresponds to strong financial inclusion (Sarma, 2015).

Choice of parameters ${ }^{7} \omega_{i}, m_{i}, M_{i}$

The three dimensions considered are all important to the financial inclusion of populations and therefore should ideally have the same weight. However, due to the unavailability of data providing complete information about the usage of financial services, we assign relatively less weight to the Usage dimension. Indeed, examining statistics on the volume of credit, deposits, and mobile money transactions gives incomplete information on the actual use of financial services.

\subsection{Specification of the Panel Model}

The specified model will be:

$$
\begin{array}{r}
\operatorname{lSIFI}_{i, t}=f\left(\operatorname{lPIB}_{i, t}, \operatorname{lAGRI}_{i, t}, \operatorname{lCRETAT}_{i, t}, \operatorname{lMOBILE}_{i, t},\right. \\
\text { lALPHA } \left._{i, t}, \operatorname{IPOPR}_{i, t}, \operatorname{IINTERB}_{i, t}\right)
\end{array}
$$

where SIFI is the synthetic index of financial inclusion of country $i$ at a period $t$. For the explanatory variables: PIB is real GDP per capita; AGRI is the weight of agriculture in GDP, CRETAT is the credit granted by banks to the government; MOBILE is the mobile phone penetration; ALPHA is the adult literacy rate; POPR is the proportion of rural population; and INTERB is the interbank credit. The logarithms of these variables are used in the model. Most of these variables are

${ }^{7}$ For PENETRATION, $\omega_{i}=1, M_{i}=2500$, and $m_{i}=0$. For AVAILABILITY, $\omega_{i}=0.5, M_{i}=60$ for branches and 120 for ATMs, and $m_{i}=0$. For USAGE, $\omega_{i}=0.5, M_{i}=300$, and $m_{i}=0$. These standards are taken from Sarma (2015). 
taken from the existing literature ${ }^{8}$ on financial inclusion that we have adapted for the WAEMU context.

In addition to these explanatory variables, two interactive ${ }^{9}$ variables are calculated and introduced into the model, always with the aim of having more factors to explain financial inclusion. The first is the variable CRETAGRI, which is the product of the bank loans granted to the government and the weight of agriculture in GDP, abbreviated (CRETAT * AGRI)i, t. This interactive variable enables us to measure the effects on financial inclusion of the credits that banks grant to the state once it allocates them to finance agriculture. The second interactive variable is ALPHARUR, which is the product of the adult literacy rate and the proportion of rural population, abbreviated (ALPHA * POPR)i, t. This variable captures the impact of rural-oriented literacy on financial inclusion.

The unavailability of long series makes empirical studies on this topic rather complex. In WAEMU countries, data are only available (integrally) from 2004 onwards. This yields an insufficient number of annual observations, violating the classical assumptions of statistical inference on time series. By including the double temporal and spatial dimension in the analysis through a panel, it is partially possible not only to remove this methodological pitfall, but also to take into account a certain unobserved heterogeneity. We initially perform three types of stationarity tests-Levin-Lin-Chu (LLC), Im-Pesaran-Shin (IPS), and Hadri $\mathrm{LM}-$ after which all our variables are stationary in level.

\section{Results and Discussions}

\subsection{Presentation and Evolution of SIFI of WAEMU Countries (Figure 1)}

Overall, there is an increase in the financial inclusion level in all eight WAEMU countries over the period 2004 to 2017. Niger and Guinea Bissau are the two WAEMU countries where financial inclusion is lowest. Benin, Togo, and Senegal have higher levels of financial inclusion than the other countries. Finally, the 2017 ranking of WAEMU countries according to their financial inclusion level is: (Table 3).

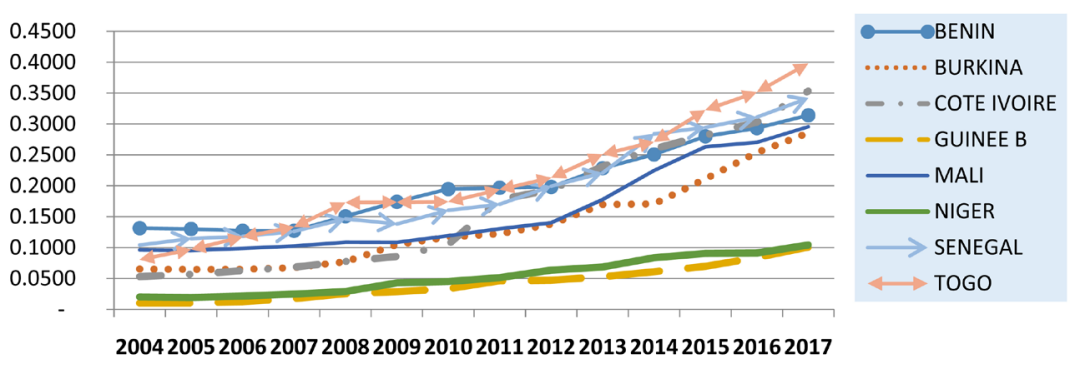

Figure 1. Evolution of the SIFI in the WAEMU zone. Source: Author's calculations from CBWAS data.

\footnotetext{
${ }^{8}$ Allen et al. (2016), Kidanemariam \& Makina (2015), and Sarma \& Pais (2011).

${ }^{9}$ The idea of interactive variables comes from Beck et al. (2007), who introduce a number of interactive variables in an econometric study on financial development.
} 
Table 3. Ranking of WAEMU countries according to SIFI (2017).

\begin{tabular}{ccc}
\hline Ranking & Synthetic index of financial inclusion (SIFI) 2017 \\
\hline $\mathbf{1}^{\mathrm{er}}$ & TOGO & 0.3982 \\
$\mathbf{2}^{\mathbf{e}}$ & COTE D'IVOIRE & 0.3530 \\
$\mathbf{3}^{\mathbf{e}}$ & SENEGAL & 0.3419 \\
$\mathbf{4}^{\mathbf{e}}$ & BENIN & 0.3142 \\
$\mathbf{5}^{\mathbf{e}}$ & MALI & 0.2955 \\
$\mathbf{6}^{\mathbf{e}}$ & BURKINA & 0.2853 \\
$\mathbf{7}^{\mathbf{e}}$ & NIGER & 0.1014 \\
$\mathbf{8}^{\mathbf{e}}$ & GUINNEA-BISSAU & 0.1007 \\
\hline
\end{tabular}

Source: Author's calculations from CBWAS data.

Using our composite index, we can now classify the eight WAEMU countries according to their SIFI level. This ranking could serve as a barometer for the implementation of work on the regional financial inclusion strategy. We can thus classify the countries of the WAEMU into 3 groups. The first is composed of countries with a relatively high financial inclusion (SIFI $\geq 0.30$ ). These are Togo (0.3982), Côte d'Ivoire (0.3530), Senegal (0.3419), and Benin (0.3142). The second group is made up of countries with an average financial inclusion $(0.30>$ SIFI $\geq 0.15)$. In this case we have two countries, Mali (0.2955) and Burkina Faso (0.2853). Finally, the third group characterizes countries with a very low financial inclusion level (SIFI < 0.15). Niger $(0.1014)$ and Guinea-Bissau $(0.1007)$ are the lowest two WAEMU countries by SIFI ranking.

Table 4 compares two different rankings of the level of financial inclusion of WAEMU countries. The first is based on the composite index that we calculate as part of this paper (SIFI). The second comes from the World Bank's Global FINDEX data. This comparison reveals three major findings. The last three countries in the SIFI classification are the same for the FINDEX classification. Further, Côte d' Ivoire, Togo, and Benin are in the top four in both classifications. The third observation, which is surprising, is that Senegal has moved from 1st place (SIFI classification) to 5th place (FINDEX classification). In the other direction, Mali moves from 5th place according to SIFI to 2nd place according to FINDEX 2014. Thus, ranking from a single dimension of financial inclusion (FINDEX) changes by integrating other dimensions.

\subsection{Econometric Results}

To achieve our objectives, our method leads us to estimate four models separately. As shown in the table below, estimation using the Ordinary Least Squares (OLS) method was used for Models 1 and 2, while the Generalized Least Squares (GLS) method was used for Models 3 and 4. Table 5 summarizes the different regressions of our analysis. Model 1 is the basic model that uses control variables only. Interactive variables were used in Models 2, 3, and 4. 
Table 4. Comparison of rankings from SIFI and Global FINDEX 2014.

\begin{tabular}{cccccc}
\hline & SIFI 2014 & & \multicolumn{3}{c}{ GLOBAL FINDEX 2014 } \\
\hline RANKING & COUNTRY & SCORE & RANKING & COUNTRY & POPORTION \\
\hline $\mathbf{1}^{\text {er }}$ & SENEGAL & 0.2839 & $1 \mathrm{er}$ & COTE D'IVOIRE & $34.32 \%$ \\
$\mathbf{2}^{\mathbf{e}}$ & TOGO & 0.2710 & $2 \mathrm{e}$ & MALI & $20.08 \%$ \\
$\mathbf{3}^{\mathbf{e}}$ & COTE D'IVOIRE & 0.2597 & $3 \mathrm{e}$ & TOGO & $18.25 \%$ \\
$\mathbf{4}^{\mathbf{e}}$ & BENIN & 0.2506 & $4 \mathrm{e}$ & BENIN & $16.62 \%$ \\
$\mathbf{5}^{\mathbf{e}}$ & MALI & 0.2245 & $5 \mathrm{e}$ & SENEGAL & $15.42 \%$ \\
$\mathbf{6}^{\mathbf{e}}$ & BURKINA & 0.1705 & $6 \mathrm{e}$ & BURKINA & $14.36 \%$ \\
$\mathbf{7}^{\mathbf{e}}$ & NIGER & 0.0834 & $7 \mathrm{e}$ & NIGER & $6.71 \%$ \\
$\mathbf{8}^{\mathbf{e}}$ & GUINEA B & 0.0609 & $8 \mathrm{e}$ & GUINEA B & ND \\
\hline
\end{tabular}

Source: Author's calculations from CBWAS data and Global FINDEX 2014 data.

Table 5. Results of regressions.

\begin{tabular}{|c|c|c|c|c|}
\hline $\begin{array}{c}\text { Period } \\
2004 \text { to } 2017\end{array}$ & $\begin{array}{l}\text { MODEL } 1 \\
\text { By OLS }\end{array}$ & $\begin{array}{l}\text { MODEL } 2 \\
\text { by OLS }\end{array}$ & $\begin{array}{l}\text { MODEL } 3 \\
\text { by GLS }\end{array}$ & $\begin{array}{l}\text { MODEL } 4 \\
\text { by GLS }\end{array}$ \\
\hline $\begin{array}{l}\text { Real GDP per capita } \\
\text { (PIB) }\end{array}$ & $\begin{array}{l}1.542174 \\
(0.001)^{\star * \star}\end{array}$ & $\begin{array}{l}3.453238 \\
(0.000)^{\star \star \star}\end{array}$ & $\begin{array}{c}1.483872 \\
(0.002)^{\star * *}\end{array}$ & $\begin{array}{l}1.477419 \\
(0.002)^{\star * *}\end{array}$ \\
\hline $\begin{array}{l}\text { Mobile phone penetration } \\
\text { (Mobile) }\end{array}$ & $\begin{array}{l}0.0879871 \\
(0.024)^{\star *}\end{array}$ & $\begin{array}{l}0.2601325 \\
(0.000)^{\star \star \star}\end{array}$ & $\begin{array}{l}0.4161098 \\
(0.000)^{* * *}\end{array}$ & $\begin{array}{l}0.4078781 \\
(0.000)^{\star * *}\end{array}$ \\
\hline $\begin{array}{l}\text { Rural Population rate } \\
\qquad \text { (Popr) }\end{array}$ & $\begin{array}{l}-4.392873 \\
(0.020)^{\star \star}\end{array}$ & $\begin{array}{l}0.00000 \\
(0.000)\end{array}$ & $\begin{array}{c}6.415178 \\
(0.000)^{\star \star \star}\end{array}$ & $\begin{array}{l}6.802618 \\
(0.000)^{* * *}\end{array}$ \\
\hline $\begin{array}{c}\text { Adult literacy rate } \\
\text { (Alpha) }\end{array}$ & $\begin{array}{l}0.4671693 \\
(0.025)^{\star \star \star}\end{array}$ & $\begin{array}{l}0.2544899 \\
(0.334)\end{array}$ & $\begin{array}{c}2.310852 \\
(0.001)^{\star * *}\end{array}$ & $\begin{array}{l}2.470759 \\
(0.000)^{\star * *}\end{array}$ \\
\hline $\begin{array}{l}\text { Credit granted by banks to government } \\
\text { (Cretat) }\end{array}$ & $\begin{array}{c}0.0095981 \\
(0.636)\end{array}$ & $\begin{array}{l}0.1732874 \\
(0.022)^{\star *}\end{array}$ & $\begin{array}{c}-0.03521 \\
(0.541)\end{array}$ & $\begin{array}{l}0.3834764 \\
(0.137)\end{array}$ \\
\hline $\begin{array}{l}\text { Weight of agriculture in GDP } \\
\text { (Agri) }\end{array}$ & $\begin{array}{c}-0.0682729 \\
(0.803)\end{array}$ & $\begin{array}{c}0.00000 \\
(0.000)\end{array}$ & $\begin{array}{l}0.0923636 \\
(0.790)\end{array}$ & $\begin{array}{c}-1.356619 \\
(0.147)\end{array}$ \\
\hline $\begin{array}{l}\text { interbank credit } \\
\text { (Interb) }\end{array}$ & $\begin{array}{c}-0.0442755 \\
(0.040)^{\star *}\end{array}$ & $\begin{array}{c}-0.0151946 \\
(0.572)\end{array}$ & $\begin{array}{c}0.0056108 \\
(0.923)\end{array}$ & $\begin{array}{c}0.0084372 \\
(0.883)\end{array}$ \\
\hline $\mathrm{C}$ & $\begin{array}{l}-15.41228 \\
(0.000)^{\star * *}\end{array}$ & $\begin{array}{l}-15.12621 \\
(0.000)^{\star * *}\end{array}$ & $\begin{array}{l}-7.725357 \\
(0.001)^{\star * *}\end{array}$ & $\begin{array}{l}-9.177621 \\
(0.000)^{\star * *}\end{array}$ \\
\hline $\begin{array}{c}\text { CRETAGRI } \\
(\text { Cretat * Agri) }\end{array}$ & $\begin{array}{c}0.00000 \\
(0.000)\end{array}$ & $\begin{array}{l}0.1495847 \\
(0.022)^{\star *}\end{array}$ & $\begin{array}{l}0.00000 \\
(0.000)\end{array}$ & $\begin{array}{c}0.3568344 \\
(0.095)^{\star}\end{array}$ \\
\hline $\begin{array}{l}\text { ALPHARUR } \\
\text { (Alpha * Popr) }\end{array}$ & $\begin{array}{c}0.00000 \\
(0.000)\end{array}$ & $\begin{array}{l}0.00000 \\
(0.000)\end{array}$ & $\begin{array}{l}4.110451 \\
(0.002)^{\star *}\end{array}$ & $\begin{array}{c}4.405903 \\
(0.001)^{\star * *}\end{array}$ \\
\hline $\mathrm{R} 2$ & 0.8948 & 0.8217 & 0.6255 & 0.6437 \\
\hline F Fisher or Wald & 117.92 & 75.28 & 140.85 & 146.06 \\
\hline$p$-value & 0.0000 & 0.0000 & 0.0000 & 0.0000 \\
\hline Observations & 112 & 112 & 112 & 112 \\
\hline
\end{tabular}

(): $p$-value coefficients in parentheses. Asterisks denote significance at the ${ }^{\star * *} 1 \%,{ }^{*} 5 \%$, and ${ }^{\star} 10 \%$ level. Source: Author's estimations from CBWASand World Development Indicator (World Bank) data. 
We first analyze the impact of control variables. The real GDP coefficient is significant at the $1 \%$ level and has a positive sign. A high real GDP favors strengthening financial inclusion in WAEMU countries. This result confirms previous studies on this topic. In addition, the gap of access to banks or even financial inclusion in the large sense between developed and developing countries could be explained by the level of their respective incomes.

The bank credit granted to the government is significant at the $5 \%$ level (Model 2), i.e. the government's indebtedness to the banking system is a determinant of financial inclusion. However, the sign changes according to the estimation method. For the basic model (Model 1), credit to the government has a positive sign, i.e., the more banks grant credit to the government, and the stronger the financial inclusion is. This is understandable if the government expends this credit in investments that lead beneficiaries to use conventional financial products and services or if the government pays wages by banking its employees. The negative sign of this variable (Model 3) can be interpreted as a use of credit by the government for other purposes not mentioned above. In these cases, granting credit to the government by the banking system at the expense of households and individuals in need is likely to discourage financial inclusion.

The mobile phone penetration rate is significant at the $5 \%$ level and influences financial inclusion positively. Mobile phone penetration in WAEMU countries has increased rapidly over the last 10 years. It recorded an average annual growth rate of more than $50 \%$ between 2005 and 2015. This shows that ICTs offer good opportunities to take advantage of via Mobile Banking (MB). The latter then constitutes an innovative approach to disseminate financial services and bank excluded populations, as demonstrated by experiences in Kenya and South Africa. The results of this study show that in WAEMU countries mobile phone usage appears to be a potential instrument for increasing and strengthening financial inclusion.

A high proportion of rural population discourages financial inclusion. This variable's coefficient has a negative sign and is significant at the 5\% level. The financial inclusion index represented in this study by SIFI takes into account the access and usage dimensions of financial services. However, usage is associated with a certain level of education, which is at its lowest level in rural areas in WAEMU countries. It is this fact that explains the negative impact of the proportion of rural populations on financial inclusion. In other words, urbanization contributes to strengthening inclusion.

The adult literacy rate has a positive and significant sign at the $5 \%$ level. The more literate people become, the more likely they are to use the formal financial system. A country's education level in general is an increasing function of its financial inclusion level. For example, Niger, which has the lowest financial inclusion level in the WAEMU, also has the lowest literacy rate.

The weight of agriculture in GDP is not statistically significant in Model 1. 
However, its negative sign gives us interesting information. Indeed, this variable is a proxy for the weight of the informal sector, and the importance of the informal sector in GDP explains in part the low level of financial inclusion achieved by WAEMU countries.

Interbank credit is significant at the $5 \%$ level and has a negative sign. Thus, the loans that banks grant each other are likely to discourage financial inclusion. This type of credit is granted at the expense of bank customers for reasons of speculation or solidarity between banks. However, if banks choose to reduce it to finance SMEs/SMIs, this would probably reverse the low financial inclusion situation.

We analyze the impact of our interaction variables. The interactive variable CRETAGRI [(CRETAT * AGRI)i, $t$ ] is significant at the $5 \%$ threshold (Model 2). The combination of these two variables has a positive effect on financial inclusion. Thus, if the credits that banks grant to the government are earmarked for financing and modernizing agriculture, financial inclusion will be strengthened. Indeed, agricultural production in these countries is quasi-informal, insofar as it is practiced by financially excluded populations using the most rudimentary techniques. Although this agricultural activity comprises about $40 \%$ of GDP, only less than $3 \%$ of bank credits are directed towards financing such agriculture. Increasing agricultural financing through state credits is likely to increase financial inclusion through rural farmers, who will thus be integrated into the formal financial system.

As for the second interactive variable, ALPHARUR [(ALPHA * POPr)i, $t$ ], it has a positive impact on SIFI and is statistically significant at the $5 \%$ level (Model 3). It captures the impact of rural-oriented literacy on financial inclusion. Thus, programs aimed at increasing the level of adult literacy in rural areas effectively contribute to increasing financial inclusion in WAEMU countries. The usage of certain financial services requires a minimum level of education. However, in rural areas of WAEMU countries, the overwhelming majority of people do not know how to read or write. This may partly explain the low level of financial inclusion in rural areas of those countries.

\section{Conclusion}

Financial inclusion is an important global issue. The Central Bank of West African States $(C B W A S)$ has made it a top priority with the adoption of a regional financial inclusion strategy along with many other actions designed to strengthen financial inclusion in the zone. Despite all the efforts to make financial services accessible for all population segments in WAEMU, financial inclusion is still very low to date, according to Global FINDEX data. In this paper, we have tried to analyze the factors explaining this low level of financial inclusion through a panel econometric model for the eight WAEMU member countries over the period of 2004 to 2017. We have designed a synthetic index of financial inclusion (SIFI) to fill the gaps in the current method of calculating the financial inclusion 
level in the WAEMU zone. Using SIFI we have classified the countries of this zone into 3 separate groups. The first is composed of countries with a relatively high financial inclusion ${ }^{10}$ (SIFI $\geq 0.30$ ). These are Togo, Côte d'Ivoire, Senegal, and Benin. The second group is made up of countries with an average financial inclusion $(0.30>$ SIFI $\geq 0.15)$. In this group, we have two countries, Mali and Burkina Faso. Finally, the third group includes countries with a very low financial inclusion level (SIFI < 0.15), namely Niger and Guinea-Bissau.

Moreover, our regression shows that real GDP, mobile phone penetration, and literacy rates increase financial inclusion as measured by SIFI. Conversely, the weight of the rural population and interbank credit are negatively associated with financial inclusion. We have also found that agricultural financing through bank lending to the government is likely to increase financial inclusion. Another economic policy implication demonstrated through our results is the positive impact of rural-oriented literacy on financial inclusion. In the future, policies should be focused on these two channels to effectively foster financial inclusion in the WAEMU.

In terms of economic policies, the Government and the Central Bank have to focus on the development of SMEs through the program called "SMEs Support Program" which already exists in the zone. This could increase the income of micro-producers and households and consequently raise the level of real GDP which will have important impact on financial inclusion. Also, there is a need to rethink education policy in general and adult literacy in particular. This action will improve the financial literacy competencies of the populations and stimulate financial inclusion. Regarding mobile phone penetration, Governments of WAEMU countries must take incentive measures to reduce costs for the mobile companies to extend their network to reach excluded populations in rural area and to have in return a positive impact on financial inclusion.

This study presents two major limitations which could be postponed for further research. The first relates to the synthetic index that we calculated by considering 3 dimensions: penetration, availability and use. It would be interesting to add a fourth dimension relating to the quality of financial services (which is difficult to quantify at the moment) to make the SIFI more representative of financial inclusion. The second limitation is related to the study period which is relatively short. In fact, given the unavailability of data from CBWAS, we carried out the econometric analysis over the period from 2004 to 2017. Reconsidering a longer period would certainly improve the robustness of the results and could make all the model variables significant.

\section{Conflicts of Interest}

The authors declare no conflicts of interest regarding the publication of this paper.

${ }^{10}$ Only relative to the WAEMU zone, as all countries in this zone have low financial inclusion level compared to the rest of the world. 


\section{References}

Allen, F., Demirguc-Kunt, A., Klapper, L., Soledad, M., \& Peria, M. (2016). The Foundations of Financial Inclusion: Understanding Ownership and Use of Formal Accounts. Journal of Financial Intermediation, 27, 1-30. https://doi.org/10.1016/j.jfi.2015.12.003

Alliance for Financial Inclusion (2010). Mesurer l'inclusion financière pour les organismes régulateurs: Conception et réalisation d'enquêtes. Document politique de l'AFI. Kuala Lumpur: Alliance for Financial Inclusion.

Beck, T., Demirguc-Kunt, A., \& Martinez Peria, M. S. (2007). Reaching out: Access to and Use of Banking Services across Countries. Journal of Financial Economics, 85, 234-266. https://doi.org/10.1016/j.jfineco.2006.07.002

Bruhn, M., \& Love, I. (2014). The Real Impact of Improved Access to Finance: Evidence from Mexico. The Journal of Finance, 69, 1347-1376. https://doi.org/10.1111/jofi.12091

Carbo, S., Gardener, E. P. M., \& Molyneux, P. (2005). Financial Exclusion. London: Palgrave MacMillan. https://doi.org/10.1057/9780230508743

Chakravarty, S. R., \& Rupayan, P. (2010). Measuring Financial Inclusion: An Axiomatic Approach. WP-2010-003, Mumbai: Indira Gandhi Institute of Development Research.

Chithra, N., \& Selwam, M. (2013). Determinants of Financial Inclusion: An Empirical Study: On the Inter-State Variations in India. https://doi.org/10.2139/ssrn.2296096

Demirguc-Kunt, A., \& Klapper, L. (2012a). Financial Inclusion in Africa: An Overview. Document de travail consacré à la recherche sur les politiques, No. 6088, Washington DC: Banque Mondiale. https://doi.org/10.1596/1813-9450-6088

Demirguc-Kunt, A., \& Klapper, L. (2012b). Measuring Financial Inclusion: The Global Findex Database. Document de travail consacré à la recherche sur les politiques, No. 6025, Washington DC: Banque mondiale. https://doi.org/10.1596/1813-9450-6025

Demirguc-Kunt, A., \& Levine, R. (2008). Finance, Financial Sector Policies, and Long-Run Growth. World Bank Policy Research Working Paper, No 11, Washington DC: World Bank. https://doi.org/10.1596/1813-9450-4469

Fungáčová, Z., \& Weill, L. (2015). Understanding Financial Inclusion in China. China Economic Review, 34, 196-206. https://doi.org/10.1016/j.chieco.2014.12.004

Gloukoviezoff, G. (2004). De la bancarisation de masse à l'exclusion bancaire puis sociale. Revue française des affaires sociales, 3, 9-38. https://doi.org/10.3917/rfas.043.0009

Guerineaun, S., \& Jacolin, L. (2014). L'inclusion financière en Afrique subsaharienne: faits stylisés et déterminants. Revue d'économie financière, 4, 57-80. https://doi.org/10.3917/ecofi.116.0057

Gupte, R., Bhama V., \& Deepa, G. (2012). Computation of Financial Inclusion Index for India. Procedia-Social and Behavioral Sciences, 37, 133-149. https://doi.org/10.1016/j.sbspro.2012.03.281

Gursharan Singh, K. (2011). Developing an Index of Financial Inclusion. Amritsar: Guru Arjan Dev Institute of Development Studies.

Honohan, P. (2008). Cross-Country Variation in Household Access to Financial Services. Journal of Banking and Finance, 32, 2493-2500. https://doi.org/10.1016/j.jbankfin.2008.05.004

Honohan, P., \& Beck, T. (2007). Making Finance Work for Africa. Washington DC: World Bank. https://doi.org/10.1596/978-0-8213-6909-8

Kempson, E., Atkinson, A., \& Pilley, O. (2004). Policy Level Response to Financial Exclusion in Developed Economies: Lessons for Developing Countries. Bristol: Personal Finance 
Research Centre, University of Bristol.

Kidanemariam, G., \& Makina, D. (2015). Financial Inclusion in Africa: Evidence Using Dynamic Panel Data Analysis. ResearchGate. https://www.researchgate.net/publication/281107667

Kuldeep, S., \& Kondan, S. (2012). Financial Inclusion, Development and Its Determinants: An Empirical Evidence of Indian States. The Asian Economic Review, 53, 115-134.

Leyshon, A., \& Thrift, N. (1995). Geographies of Financial Exclusion: Financial Abandonment in Britain and the United States. Transactions of the Institute of British Geographers New Series, 20, 312-341. https://doi.org/10.2307/622654

Nitin, K. (2012). Financial Inclusion and Its Determinants: Evidence from State Level Empirical Analysis in India. Mumbai: Indira Gandhi Institute of Development \& Research.

Sangaré, M. (2013). La microfinance: Quels liens entre les modèles de financement des institutions et la qualité des services offerts aux clients (342 p). Thèse de doctorat en Sciences économiques, Toulouse: Université Toulouse 1 Capitole.

Sarma, M. (2008). Index of Financial Inclusion. Working Paper No. 215, New Delhi: Indian Council for Research on International Economic Relations.

Sarma, M. (2015). Measuring Financial Inclusion. Economics Bulletin, 35, 604-611.

Sarma, M., \& Pais, J. (2011). Financial Inclusion and Development: A Cross Country Analysis. New Delhi: Indian Council for Research on International Economic Relations.

Servet, J.-M. (2006). Banquiers aux pieds nus, la microfinance. Paris: Éditions Odile Jacob.

Sinclair, S. P. (2001). Financial Exclusion: An Introductory Survey. Edinburgh: Centre for Research in Socially Inclusive Services, Heriot-Watt University.

Walras Centre (1999, 2000, 2001, 2002, 2004). Reports of Walras Centre. Paris: Editions Economica.

Zins, A., \& Weill, L. (2016). The Determinants of Financial Inclusion in Africa. Review of Development Finance, 6, 46-57. https://doi.org/10.1016/j.rdf.2016.05.001 